\title{
Polymorphisms of the low-density lipoprotein receptor gene in Brazilian individuals with heterozygous familial hypercholesterolemia
}

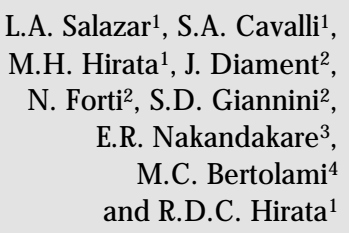

L.A. Salazar ${ }^{1}$, S.A. Cavalli ${ }^{1}$, M.H. Hirata ${ }^{1}$, J. Diament ${ }^{2}$, N. Forti2 ${ }^{2}$ S.D. Giannini², E.R. Nakandakare3, M.C. Bertolami ${ }^{4}$ and R.D.C. Hirata ${ }^{1}$

\author{
'Departamento de Análises Clínicas e Toxicológicas, \\ Faculdade de Ciências Farmacêuticas, "Instituto do Coração, and \\ ${ }^{3}$ Divisão de Endocrinologia, Hospital das Clínicas, Faculdade de Medicina, \\ Universidade de São Paulo, São Paulo, SP, Brasil \\ ${ }^{4}$ Instituto Dante Pazzanese de Cardiologia, São Paulo, SP, Brasil
}

\section{Correspondence \\ L.A. Salazar \\ Departamento de Análises Clínicas e Toxicológicas, FCF, USP \\ Av. Prof. Lineu Prestes, 580, B17 \\ 05508-900 São Paulo, SP \\ Brasil \\ Fax: + 55-11-813-2197 \\ E-mail: luisn@ usp.br}

Research supported by FAPESP and CAPES. L.A. Salazar is the recipient of a FAPESP fellowship (No. 98/09759-8).

Received March 15, 2000 Accepted July 25, 2000

\section{Abstract}

Familial hypercholesterolemia (FH) is a metabolic disorder inherited as an autosomal dominant trait characterized by an increased plasma low-density lipoprotein (LDL) level. The disease is caused by several different mutations in the LDL receptor gene. Although early identification of individuals carrying the defective gene could be useful in reducing the risk of atherosclerosis and myocardial infarction, the techniques available for determining the number of the functional LDL receptor molecules are difficult to carry out and expensive. Polymorphisms associated with this gene may be used for unequivocal diagnosis of FH in several populations. The aim of our study was to evaluate the genotype distribution and relative allele frequencies of three polymorphisms of the LDL receptor gene, $\mathrm{HincII}_{1773}$ (exon 12), AvaII (exon 13) and PvuII (intron 15), in 50 unrelated Brazilian individuals with a diagnosis of heterozygous FH and in 130 normolipidemic controls. Genomic DNA was extracted from blood leukocytes by a modified salting-out method. The polymorphisms were detected by PCR-RFLP. The FH subjects showed a higher frequency of $\mathrm{A}+\mathrm{A}+\left(\right.$ AvaII), $\mathrm{H}+\mathrm{H}+\left(\right.$ HincII $\left.{ }_{1773}\right)$ and $\mathrm{P} 1 \mathrm{P} 1$ (PvuII) homozygous genotypes when compared to the control group $(\mathrm{P}<0.05)$. In addition, $\mathrm{FH}$ probands presented a high frequency of $\mathrm{A}+(0.58), \mathrm{H}+$ $(0.61)$ and P1 (0.78) alleles when compared to normolipidemic individuals $(0.45,0.45$ and 0.64 , respectively). The strong association observed between these alleles and $\mathrm{FH}$ suggests that AvaII, HincII ${ }_{1773}$ and $P v u$ II polymorphisms could be useful to monitor the inheritance of FH in Brazilian families.

\section{Key words}

- Familial hypercholesterolemia - DNA polymorphism

- Atherosclerosis

- Genetics

- LD L receptor 
Familial hypercholesterolemia $(\mathrm{FH})$ is a common autosomal dominant disease with an estimated world prevalence of $0.2 \%$ (1). It is caused by defects in the gene coding for the low-density lipoprotein receptor (LDLR) preventing normal clearance of plasma LDL. The disease is clinically characterized by elevated LDL-cholesterol (LDL-C) levels in blood, tendon xanthomas, and premature coronary heart disease (1). However, these symptoms are not always present, especially in children, and hence do not allow an unequivocal diagnosis. As an appropriate diet and drug treatment of FH patients can reduce their risk of future coronary heart disease, it would be advantageous to identify the affected subjects before the onset of clinical symptoms. Thus, molecular characterization of the LDLR gene appears to be a useful tool for diagnosis. It has been demonstrated that the disease is caused by several different mutations in the LDLR gene (2-5). Although the early identification of individuals carrying the defective gene could be useful in reducing the risk of atherosclerosis and myocardial infarction, the available techniques for determining the number of the functional LDLR molecules are difficult and expensive. However, several authors have shown that polymorphisms associated with this gene may be used to monitor the inheritance of the defective allele in FH families (6-8).

In the present study, we report the genotype distribution and the relative allele frequencies for three polymorphisms of the LDLR gene, HincII $_{1773}$ (exon 12), AvaII (exon 13) and PvuII (intron 15), in 50 unrelated Brazilian individuals clinically diagnosed as FH heterozygotes and in 130 normolipidemic controls.

The subjects were selected according to the following criteria: normolipidemic controls had total cholesterol levels $\leq 5.7 \mathrm{mmol} /$ 1 with LDL-C $<4.0 \mathrm{mmol} / 1$, triglycerides $\leq 1.8$ $\mathrm{mmol} / \mathrm{l}$, and a negative family history of hyperlipidemias, coronary heart disease, or other clinical signs of atherosclerosis. FH patients had total cholesterol levels $\geq 7.5$ $\mathrm{mmol} / 1$ with LDL-C $\geq 5.2 \mathrm{mmol} / \mathrm{l}$, a triglyceride level not exceeding $2 \mathrm{mmol} / \mathrm{l}$, plus two of the following: tendon xanthomas in the proband or in one or more first degree relatives, hypercholesterolemic children in the family, cholesterol levels $\geq 7.5 \mathrm{mmol} / 1$ in two or more family members, and a family history of coronary artery disease in one or more first or second degree relatives younger than 50 years, and absence of the 3500 mutation, characteristic of familial defective apolipoprotein B-100 (9). All subjects gave informed consent to participate in the study.

Serum lipid and lipoprotein concentrations were determined after an overnight $(>12 \mathrm{~h}$ ) fast by standard procedures. Genomic DNA was extracted from peripheral blood leukocytes by a salting-out procedure (10). The 3500 mutation in the apolipoprotein B100 gene was detected according to the procedure described by Cavalli et al. (11). The $A v a \mathrm{II}, H i n c \mathrm{II}_{1773}$, and $P v u \mathrm{II}$ polymorphic sites of the LDLR gene were detected by PCRRFLP, according to previously described procedures $(12,13)$. Allele frequencies and genotype distribution for each polymorphic site were estimated by gene counting. Chisquare analysis was used to test HardyWeinberg equilibrium and for comparison of allele frequencies and genotype distribution between the studied groups, with the level of significance set at $5 \%$.

Clinical details, lipid and lipoprotein concentrations (mean $\pm \mathrm{SD}$ ) in serum from 50 unrelated Caucasian FH subjects and 130 normolipidemic controls are shown in Table 1. As expected, serum total cholesterol, triglyceride and LDL-C concentrations were higher in FH subjects $(\mathrm{P}<0.0001)$. HDL-C concentrations were similar for the two groups.

All subjects, FH and controls, showed absence of the 3500 mutation in the apolipoprotein B-100 gene.

Table 2 gives the genotype distribution and the relative allele frequencies for $\mathrm{FH}$ 
patients and controls for the polymorphisms studied. None of the genotype distributions differed significantly from the one expected for a sample in Hardy-Weinberg equilibrium. The $\mathrm{FH}$ patients showed a greater frequency of $\mathrm{A}+\mathrm{A}+($ AvaII $), \mathrm{H}+\mathrm{H}+\left(H_{i n c I I} \mathrm{I}_{173}\right)$ and P1P1 (PvuII) homozygous genotypes when compared to the normolipidemic controls $\left(\chi^{2}=7.07, \mathrm{P}=0.0292 ; \chi^{2}=8.92, \mathrm{P}=\right.$ 0.0116 and $\chi^{2}=10.1, \mathrm{P}=0.0064$, respectively). In addition, $\mathrm{FH}$ probands presented a high frequency of $\mathrm{A}+, \mathrm{H}+$ and $\mathrm{P} 1$ alleles when compared to normolipidemic individuals (Table 2). However, the relative allele frequencies found in the Brazilian FH patients were similar to those for other $\mathrm{FH}$ individuals from Caucasian populations (68).

In conclusion, the strong association observed between $\mathrm{A}+, \mathrm{H}+$ and $\mathrm{P} 1$ alleles and FH suggests that $A v a \mathrm{II}, H i n c \mathrm{II}_{1773}$ and $P v u \mathrm{II}$ polymorphisms of the LDLR gene could be useful as genetic markers to monitor the inheritance of familial hypercholesterolemia in Brazilian families. However, family studies are required to support this assumption.

\section{Acknowledgments}

We are grateful to Dr. Nga Y. Nguyen (CBER, FDA, Bethesda, USA) for providing the primers used in the amplification of the LDLR gene.
Table 1 - Clinical details of Brazilian heterozygous familial hypercholesterolemia (FH) patients and normolipidemic controls.

Values are reported as mean \pm SD. ns, Nonsignificant (Student t-test).

\begin{tabular}{lccc}
\hline & FH & Controls & P \\
\hline N (female/male) & $50(40 / 10)$ & $130(85 / 45)$ & \\
Age (years) & $50.0 \pm 8.3$ & $54.1 \pm 8.8$ & $\mathrm{~ns}$ \\
Body mass index $\left(\mathrm{kg} / \mathrm{m}^{2}\right)$ & $28.4 \pm 4.7$ & $26.6 \pm 6.0$ & $\mathrm{~ns}$ \\
Total cholesterol $(\mathrm{mmol} / \mathrm{l})$ & $11.4 \pm 1.7$ & $4.4 \pm 0.6$ & $<0.0001$ \\
Triglycerides $(\mathrm{mmol} / \mathrm{l})$ & $1.3 \pm 0.4$ & $1.0 \pm 0.4$ & $<0.0001$ \\
HDL-cholesterol $(\mathrm{mmol} / \mathrm{l})$ & $1.2 \pm 0.2$ & $1.3 \pm 0.3$ & $\mathrm{~ns}$ \\
LDL-cholesterol $(\mathrm{mmol} / \mathrm{l})$ & $9.7 \pm 1.8$ & $2.7 \pm 0.6$ & $<0.0001$ \\
Presence of xanthomas $(\%)$ & 60 & 0 & \\
Positive family history of premature & 90 & 0 &
\end{tabular}

Table 2 - Comparison of genotype distribution and relative allele frequencies of three polymorphisms of the LDLR gene in Brazilian individuals with heterozygous familial hypercholesterolemia (FH) and normolipidemic controls (NC).

$a_{+} /$- Indicates presence/absence of a restriction site; bP1/P2 indicates absence/presence of a restriction site.

\begin{tabular}{|c|c|c|c|c|c|}
\hline \multirow{2}{*}{$\begin{array}{l}\text { Polymorphism } \\
\text { Avalla }^{2}\end{array}$} & \multicolumn{3}{|c|}{ Genotype distribution (\%) } & \multicolumn{2}{|c|}{ Allele frequency } \\
\hline & $A+A+$ & $A+A-$ & A-A- & $A+$ & A- \\
\hline $\mathrm{FH}(\mathrm{N}=50)$ & 34 & 48 & 18 & 0.58 & 0.42 \\
\hline \multirow[t]{2}{*}{$N C(N=130)$} & 16 & 58 & 26 & 0.45 & 0.55 \\
\hline & \multicolumn{3}{|c|}{$\chi^{2}=7.07$ (2 d.f., $\left.\mathrm{P}=0.0292\right)$} & \multicolumn{2}{|c|}{$\chi^{2}=4.38$ (1 d.f., $P=0.0364$} \\
\hline $\mathrm{Hincll}_{1773^{\mathrm{a}}}$ & $\mathrm{H}+\mathrm{H}+$ & $\mathrm{H}+\mathrm{H}-$ & $\mathrm{H}-\mathrm{H}-$ & $\mathrm{H}+$ & $\mathrm{H}-$ \\
\hline $\mathrm{FH}(\mathrm{N}=50)$ & 35 & 52 & 13 & 0.61 & 0.39 \\
\hline \multirow[t]{2}{*}{$N C(N=130)$} & 18 & 55 & 27 & 0.45 & 0.55 \\
\hline & \multicolumn{3}{|c|}{$\chi^{2}=8.92(2$ d.f., $P=0.0116)$} & \multicolumn{2}{|c|}{$\chi^{2}=6.77(1$ d.f., $P=0.0093)$} \\
\hline Pvull & P1P1 & P1P2 & $\mathrm{P} 2 \mathrm{P} 2$ & P1 & P2 \\
\hline $\mathrm{FH}(\mathrm{N}=50)$ & 64 & 29 & 7 & 0.78 & 0.22 \\
\hline \multirow[t]{2}{*}{$N C(N=130)$} & 38 & 52 & 10 & 0.64 & 0.36 \\
\hline & \multicolumn{3}{|c|}{$\chi^{2}=10.1(2$ d.f., $\mathrm{P}=0.0064)$} & \multicolumn{2}{|c|}{$\chi^{2}=5.99$ (1 d.f., $P=0.0144$} \\
\hline
\end{tabular}

\section{References}

1. Brown MS \& Goldstein J L (1986). A receptor-mediated pathway for cholesterol homeostasis. Science, 232: 34-47.

2. Hobbs H, Brown M \& Goldstein J (1992). Molecular genetics of the LDL receptor gene in familial hypercholesterolemia. Human Mutation, 1: 445-466.

3. Varret $M$, Rabes J P, Villeger $L$, J unien $C$, Beroud C \& Boileau C (1999). Analysis of the 525 point mutation in the human LDL receptor gene database. Atherosclerosis, 144: 182-183 (Abstract).
4. Alberto $\mathrm{FL}$, Figueiredo $\mathrm{MS}$, Zago $\mathrm{MA}$, Araújo AG \& Dos-Santos J E (1999). The Lebanese mutation as an important cause of familial hypercholesterolemia in Brazil. Brazilian J ournal of Medical and Biological Research, 32: 739-745.

5. Soutar AK (1998). Update on low density lipoprotein receptor mutations. Current Opinion in Lipidology, 9: 141-147.

6. Chaves FJ, Puig O, Garcia-Sogo M, Real J , Gil J V, Ascaso J , Carmena R \& Armegod ME (1996). Seven DNA polymorphisms in the $L D L$ receptor gene: application to the study of familial hypercholesterolemia in Spain. Clinical Genetics, 50: 28-35.

7. Humphries SE, King-Underwood L, Gudnason V, Seed M, Delattre S, Clavey $V \&$ Fruchart J -CH (1993). Six DNA polymorphisms in the low density lipoprotein receptor gene: their genetic relationship and an example of their use for identifying affected relatives of patients with familial hypercholesterolemia. J ournal of Medical Genetics, 30: 273-279. 
8. Puig O, Chaves FJ, Garcia-Sogo M, Real J , Gil J V, Ascaso J \& Armegod ME (1996). A three-allelic polymorphic system in exon 12 of the LDL receptor gene is highly informative for segregation analysis of familial hypercholesterolemia in the Spanish population. Clinical Genetics, 50: 5053.

9. Myant NB (1993). Familial defective apolipoprotein B-100: a review, including some comparisons with familial hypercholesterolemia. Atherosclerosis, 104: 1-18.

10. Salazar LA, Hirata MH, Cavalli SA, Machado MO \& Hirata RDC (1998). Opti- mized procedure for DNA isolation from fresh and cryopreserved clotted human blood useful in clinical molecular testing. Clinical Chemistry, 44: 1748-1750.

11. Cavalli SA, Hirata $\mathrm{MH} \&$ \& Hirata RDC (1999). Optimized procedure for detection of 3500 and 3531 mutations and Mspl polymorphism in exon 26 of the apolipoprotein B-100 gene. Brazilian J ournal of Pharmaceutical Sciences, 35: 15 (Abstract).

12. Salazar LA, Hirata MH, Giannini SD, Forti N, Diament J , Issa J \& Hirata RDC (1999). Effects of Avall and Hincll polymorphisms at the LDL receptor gene on serum lipid levels of the Brazilian individuals with high risk for coronary heart disease. J ournal of Clinical Laboratory Analysis, 13: 251-258.

13. Salazar LA, Hirata MH, Forti N, Diament J Giannini SD, Issa J \& Hirata RDC (2000). Pvull intron 15 polymorphism at the LDL receptor gene is associated with differences in serum lipid concentrations in individuals with low and high risk for coronary artery disease from Brazil. Clinica Chimica Acta, 293: 75-88. 